高分子論文集 (Kobunshi Ronbunshu), Vol. 47, No. 11, pp. 889-894 (Nov., 1990)

\title{
電解重合ポリアスレン合成の最適条件
}

\author{
岩崎 賢太郎*1,*2・種田 靖夫*1 ・松本 和雄*1 ・日野 照純*1
}

（受付 1990 年 5 月 17 日・蕃査終了 1990 年 8 月 8 日）

\begin{abstract}
要 旨 アスレンを電解重合する場合の重合条件により，隄極板上に生成するポリマーの電気伝算度がどのよう に影要を受けるかを検討した，その結果，より高い電気伝導度を有する重合体を得るためには，溶媒や支持電解質

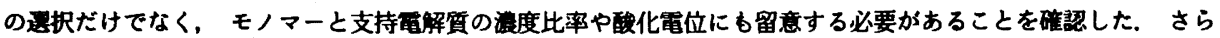
に，作用電梗面積す電気伝導度を大きく左右する要因の一っであることがかかった。この結果，最通な重合条件を

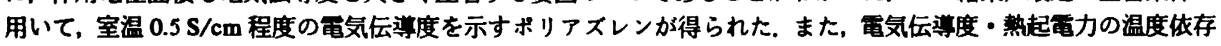
性から、ポリアスレンの電子伝達機檴か，3次元バリアフルレンジホッピングモデルにあてはまることについてる 考察した.
\end{abstract}

\section{1 楮言}

ドーピングによりポリアセチレンが高い導電率を示す ことが発見されて以来，さまざまな導電性高分子の合成 が陚みられ、それらの物性が研究されてるようになって きだ，特に電解重合法を用いて得られるピロールやチ オフェンに代表される, 複素五員環式化合物の重合体 は, ポリアセチレンと異なり空気中で安定な優れた性質 を持ち合成も比较的容易であることから，工業的応用の 方面への研究す数多くなされている2). しかし, どのよ うな化合物であってもこの方法が適用できるわけではな く, 電解重合法で合成可能な化合物は， あまり多数とは いいにくい. また, ピロールのように電解重合が可能で あっても，生成する高分子の物性の目安となる電気伝導 度は, 合成時の諸条件によって微妙に変化することが知 られている゙3. そのため, 電子素子材料をはじめとする 湢広い底用への見地加らも, 重合可能な化合物の多様化 や，その合成条件之物性の関連性の検討は，必要不可欠 であると考えられる. さらに, この研究により, 高い電 気伝惩度を与える最道な重合条件す見いだすことができ ろ.

ヘテロ原子を含まない五員桭骨格を持つアズレンは， 非交互炭化水素でありながら, 電解重合が可能であり, 生成する高分子の電気伝賞度加比较的大きいとされてい ろ". 本稿では，このアスレンの電解重合時の諸条件が, 陌梗板上に生成する重合膜の電気伝尊度に及ぼす影䈏に ついて研究した結果について述へろ. また, より電気伝

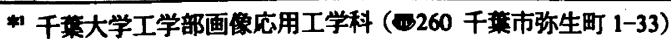

- 現在: 合研究大学院大学数物科学研究科權造分子科学尃 攻（4444 受知県岡㥓市明大寺町字西的中 38）
導度の高い重合膜を得るための最適重合条件について検 討した結果についてあ併せて報告する.

\section{2 実験方法}

\section{1 試薬}

アズレンは，市販品をエタノールから再結晶して用い た. 電解重合用の溶媒にはアセトニトリル・ベンゾニト リル・ジメチルホルムアミドを用いた。 アセトニトリル は塩化カルシウムで 72 時間乾燥後, 五酸化リン存在下 で蒸留し, 冷凍・脱気・解凍を絽り返して脱水・脱酸素 を行った。 ペンソニトリルは塩化カルシゥムで乾燥・蒸 留後, 使用直前に冷東・脱気・解凍を絽り返して脱水・ 脱酸素に努めた。 シメチルホルムアミドは塩化カルシウ ムで脱水後使用に供した．用いた支持電解質は市販のテ トラフチルアンモニウムのテトラフルオロほう酸塩 $\left(\mathrm{TBABF}_{4}\right)$ ・過塩素酸塩 $\left(\mathrm{TBAClO}_{4}\right)$ ・トリフルオロメチ ルスルホン酸塩 $\left(\mathrm{TBACF}_{3} \mathrm{SO}_{3}\right) ・ \exists ウ$ 素垣 $(\mathrm{TBAI}) \cdot 三$ ヨウ素塩 $\left(\mathrm{TBAI}_{3}\right)$ である. TBABF 4 は酢酸エチル・ベン ぜン混合溶媒から、 TBAClO4 酢酸エチルから, $\mathrm{TBACF}_{3} \mathrm{SO}_{3}$ はエタノールから, TBAI はメタノールか ら, $\mathrm{TBAI}_{3}$ はメタノールから再結晶を数回繰り返した後 に使用した。

\section{2 重合操作}

すべての重合は，アルコン置換したドライボックス中 で 3 電極方式で行った. 作用極には白金板, 参照極には, $\mathrm{Ag} / \mathrm{AgCl}$ 電極, 対極にはアルミニウム板を用いた. 作用 極には特に示さない限り $15 \mathrm{~cm}^{2}$ のものを用いた，通電 には, 北斗電工(株)製ポテンショスタット・ガルバノス タットHA301 を用いた。 
Table 1. The electrical conductivities of polyazulenes prepared by the electochemical method in various solvents and electrolytes $(\mathrm{S} / \mathrm{cm})$

\begin{tabular}{|c|c|c|c|}
\hline & BN & AN & DMF \\
\hline $\mathrm{TBA}^{-\mathrm{ClO}_{4}}$ & 0.035 & 0.0078 & 0.0021 \\
\hline TBA-BF $_{4}$ & 0.028 & 0.0088 & 0.0015 \\
\hline $\mathrm{TBA}-\mathrm{CF}_{3} \mathrm{SO}_{3}$ & 0.011 & 0.0065 & Not tested \\
\hline $\mathrm{TBA}^{-\mathrm{I}_{3}}$ & - & - & Not tested \\
\hline TBA-I & - & - & - \\
\hline
\end{tabular}

- : No film formation

$\mathrm{BN}$ : Benzonitrile ( $\mathrm{Ph}-\mathrm{CN})$

AN : Acetonitrile ( $\mathrm{Me}-\mathrm{CN})$

DMF : Dimethylformamide $\left(\mathrm{Me}_{2} \mathrm{NCHO}\right)$

\section{3 気伝型度・鄎起国力の測定}

得られた重合膜を真空乾燥した後，5 $\mathrm{mm} \times 3 \mathrm{~mm}$ に切 り，直流四端子法を用いて電気伝導度を測定した，また， 電気伝導度の温度依存性から, 活性化エネルギーを算出 した．熱起電力の測定は，文献 5 をあとにして製作した 装置を用いて行った。

\section{3 洁果と考察}

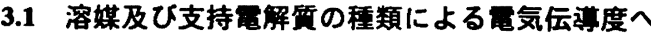 の影零}

ピロールの場合, 重合に用いる溶媒・支持電解質に よって, 得られる重合体の電気伝頱度に大きな连いがあ ることが報告されており3)， アズレンの場合においても 検討の必要があることが考えられた。 そこで, 電解重合 に用いる溶媒や支持電解質の違いによる重合体の電気伝 導度の変化を検討した。電解重合時の基本条件は，アズ レン浱度 $0.01 \mathrm{M}$, 支持電解質洤度 $0.05 \mathrm{M}$, 印加電圧 2.0 $\mathrm{v}$ である.この条件下で得られた重合体の電気伝導度を Table 1 に示す. TBAI や $\mathrm{TBAI}_{3}$ を支持電解質に用いる と重合膜が得られなかった．この原因は，アニオンの酸 化力が弱く重合が進行しなかったためと考えられる。 た ンゾニトリルを溶媒に用いるとおおむね強靱な膜が得ら れ, それらの電気伝導度は他の組合せよりも高い値で あった．また，溶媒にアセトニトリルやジメチルホルム アミドを用いた場合は，あまり丈夫な膜ができず電気伝 導度む $10^{-2} \mathrm{Scm}^{-1}$ 以下と低くかった。

溶媒にベンソニトリルを用い，支持電解質に過塩素酸 テトラフォチルンモニゥム塩 $\left(\mathrm{TBAClO}_{4}\right)$ を用いた場 合, 最も高い電気伝導度を示す重合体が得られた。用い た溶媒の種類によって電気伝導度は著しく異なってい る. ベンゾニトリルを用いた場合には，他の溶媒を用い た場合に比へて比較的高い電気伝導度を有する重合体が 得られた.これはベンソニトリルが, ジメチルホルムア ミドに比へてて, 陽極酸化によって生じたラジカルカチオ

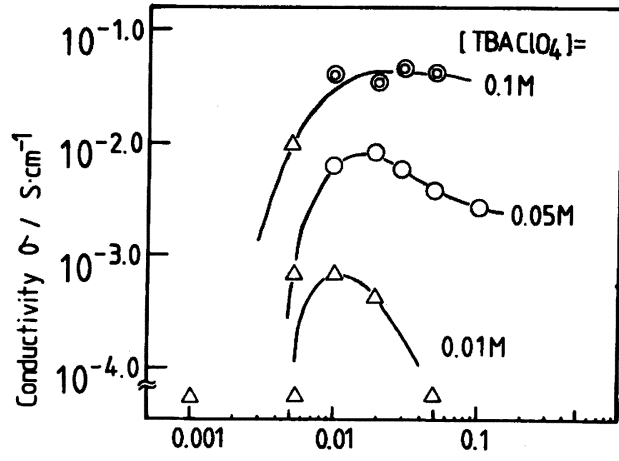

Monomer concentration $/ \mathrm{mol}^{-\mathrm{dm}} \mathrm{m}^{-3}$

Fig. 1. Relationship between the monomer concentration and the conuctivity, $\sigma$, of polyazulene.

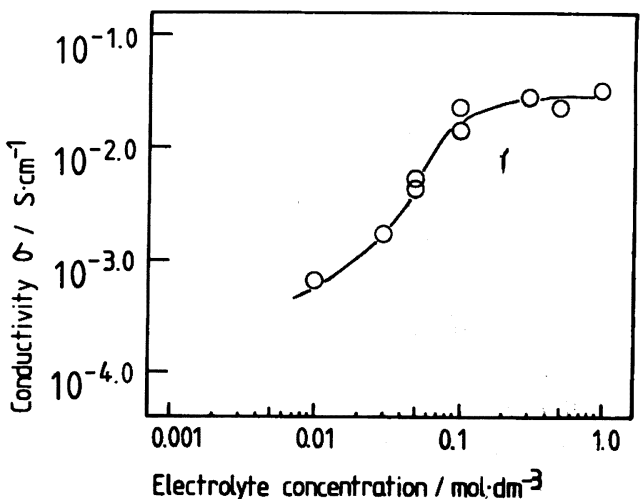

Fig. 2. Relationship between the electrolyte concentration and the conductivity, $\sigma$, of polyazulene.

ンと反応しにくく, 重合反応を妨害しないために, 電気 伝䀜度の高い強靱な重合膜が生成するためであると考え られる. また，用いた支持電解質の種類によっては重合 体の電気伝導度は大きく異なり，アニオンの酸化力の大 小が重合や重合膜の電気伝導度に大きな要素となること が明らかとなった。

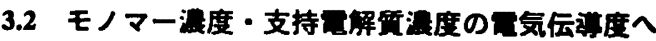 の影糸}

モノマーや支持電解質の湌度が電気伝導度へどのよう な影譩を与えるかを検討するため，高い電気伝尊度を与 える, ベンゾニトリル, 過塩素酸テトラブチルアンモ二

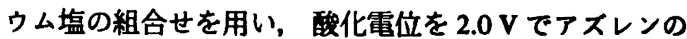
電解重合を行った。

モノマー濃度と重合体の電気伝尊度の関係を, 支持電 解質浱度をパラメーターとしてプロットした結果を Fig. 1 に示す. 図から明らかなように, モノマー湍度が低い

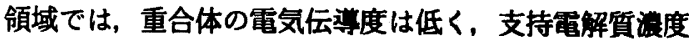




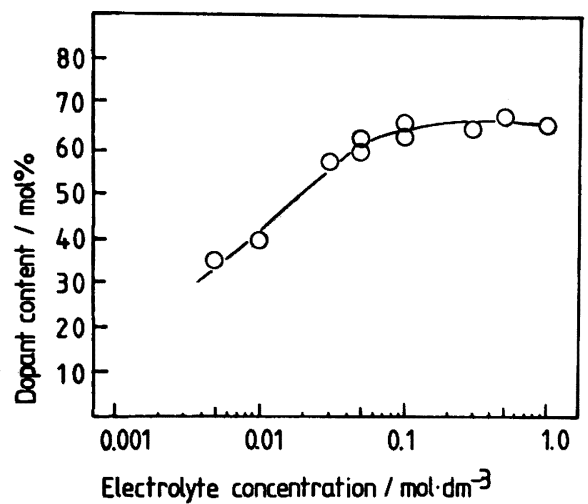

Fig. 3. Relationship between the electrolyte concentration and the dopant content of pristine polyazulene.

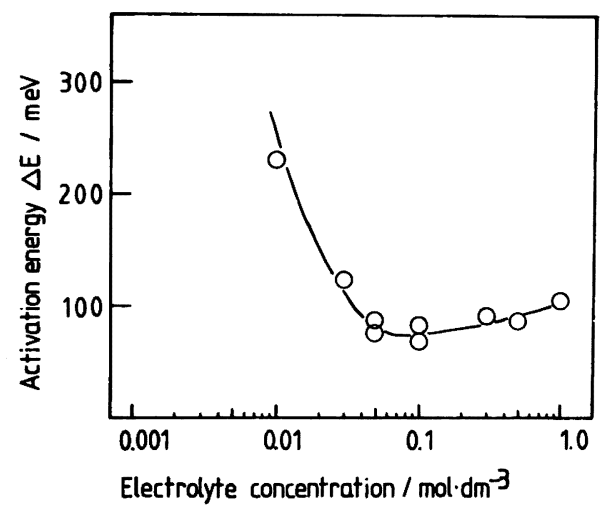

Fig. 4. Relationship between the electrolyte concentration and the activation energy, $\Delta E$, of polyazulene.

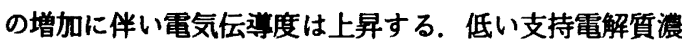
度の場合, 高い電気伝導度を与えるのに最適なモノマー 澼度が存在する. しかし, 支持電解質浱度が高い場合に は, モノマー洤度を高くしても, 電気伝覚度に顕著な变 化はあまりみられない。

これらから，低いモ/マー浱度では溶解しているモ/ マーの絶対量が少ないために，十分に長い高分子鎖が生 長せず, その結果として電気伝導度か低くなると考えら

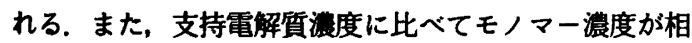
対的に高い場合には，電極付近の酸化されたモ/マーが カウンターアニオンを見つけることができず，結果とし て重合膜の電気伝孪度が低くなるすのと思われる。 いず れにしてる仕込み支持電解質篧度加重合膜の電気伝導度 に密接に関係することを示唆している.

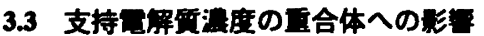

モノマー浱度を $0.01 \mathrm{M}$ に固定して合成した重合体の, 電気伝等度の仕込み支持電解質湍度依存性を Fig. 2 に示 す. 仕込み支持電解源度の上昇につれ, 重合体の電気伝

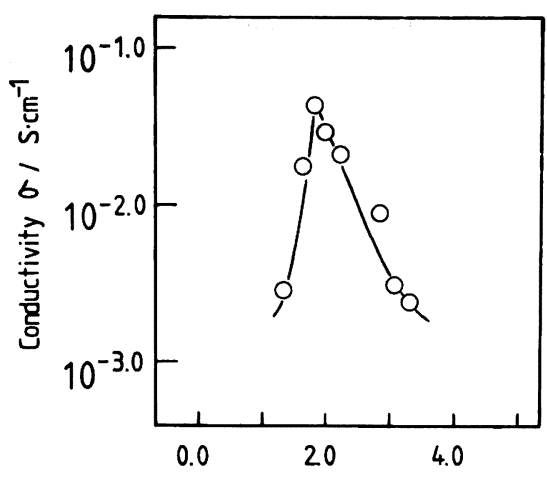

Applied voltage / V vs. Ag/AgCl

Fig. 5. Relationship between the applied voltage, $V$, and the conductivity, $\sigma$, of polyazulene.

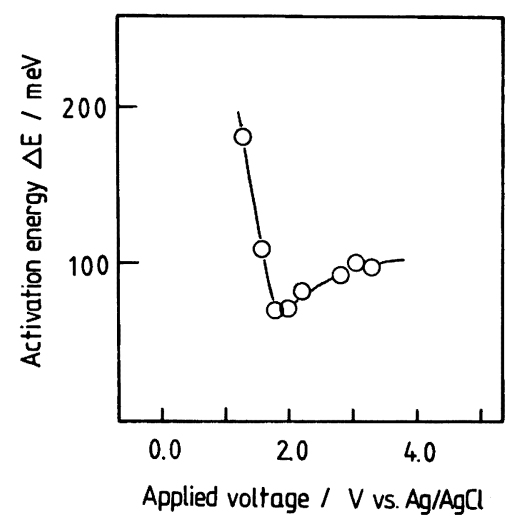

Fig. 6. Relationship between the applied voltage, $V$, and the activation energy, $\Delta E$, of polyazulene.

導度は上昇していく，しかし，支持電解質浱度が $0.1 \mathrm{M}$ より高濃度になっても, 電気伝導度はほぼ一定値をと り，それ以上上昇しない，これより，支持電解質浱度が $0.1 \mathrm{M}$ 以上になるような合成条件が好ましいといえる.

重合膜の元素分析の結果, 窒素成分は存在せず, 塩素 成分が存在することが判明した。これは, 重合体中に溶 媒や支持電解質のカチオンは含まれておらず, 支持電解 質のアニオンだけが含まれていることを意味する. した がって, 重合体の電気伝拿度を左右する要因として, 重 合体に含まれるアニオンの存在が考えられる.

重合体に含まれるアニオン量を, 仕込み支持電解質湌 度に対してプロットした結果を Fig. 3 に示す. 仕込み支 持電解質㳻度が上昇するにつれて, 重合体に含まれるア ニオン量も增えていくが, 最終的にアニオン量は約 67 mol\% で頭打ちとなる.この挙動は Fig. 2 の電気伝導度 の变動と類似しており, 電気伝導度と重合体に含まれる 
Table 2. The electrical conductivities of polyazulenes prepared by the electochemical method for various electrode sizes

\begin{tabular}{cc}
\hline \hline Size $\left(\mathrm{cm}^{2}\right)$ & Conductivity $(\mathrm{S} / \mathrm{cm})$ \\
\hline 2 & $0.5_{7}$ \\
4 & $0.4_{4}$ \\
8 & $0.1_{6}$ \\
15 & 0.05 \\
\hline
\end{tabular}

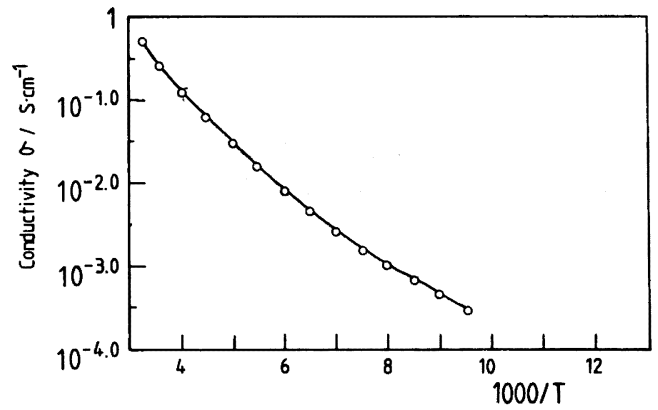

Fig. 7. $T^{-1}$ dependence of the electrical conductivity of polyazulene.

アニオン量との間に相関があることを示唆している.

重合体の電気伝導度の室温付近の温度依存性加ら, 活 性化エネルギーを求めたところ, 仕込み支持電解質浱度 により変化することがわかった。この結果を Fig. 4 に示 す. 仕込み電解質浱度が $0.01 \mathrm{M}$ 之低い場合, 活性化エネ ルギーは $240 \mathrm{meV}$ と大きいが, 浱度の増加に伴って活性 化エネルギーは減少し $0.1 \mathrm{M}$ で最小值 $80 \mathrm{meV}$ をとる.

この濃度以上では, 活性化エネルギーは緩やかに増加す るようになる.

以上のことから，仕込み支持電解質濃度が重合体に含 まれるアニオン量を左右し，これに対応して電気伝導度 や活性化エネルギーが変化するといえる.

\section{4 䣬化再位の影霊}

重合体の電気伝導度を左右する要因として, 酸化電位 あ考えられる. そこで, 溶媒にベンソニトリルを用い, アスレン溇度を $0.01 \mathrm{M}$, 過塩素酸テトラフォチルアンモ二 ウム塩の浱度を $0.1 \mathrm{M}$ に固定し, 酸化電位を変化させて 重合を行った. Fig. 5 はこの重合体の電気伝導度を, 用 いた酸化電位でプロットした結果である. $1.8 \mathrm{~V}$ (vs. Ag/ $\mathrm{AgCl})$ 付近に鋭い電気伝尊度の極大を示し, 高い電気伝 祭度を示す重合体を得るためには最適な酸化電位が存在 することが図より明らかである.

一方, 定電流電解で, 電流密度を $0.03 \sim 3.00 \mathrm{~mA} / \mathrm{cm}^{2}$ の範囲で変化させて得られた重合体の電気伝学度は，い ずれす，定電位電解で得られた重合体よりも数桁低いも

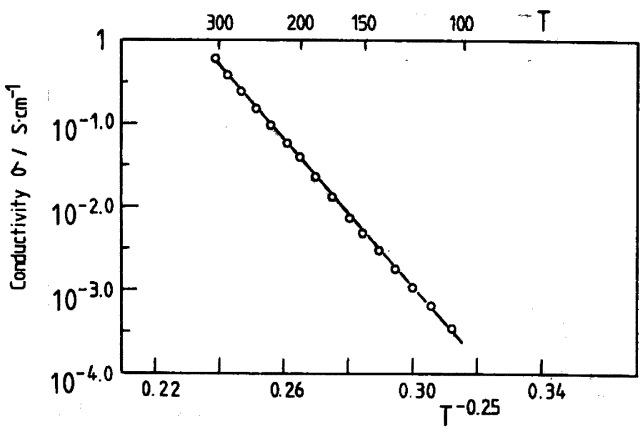

Fig. 8. Log conductivity vs. $T^{-0.25}$ for polyazulene.

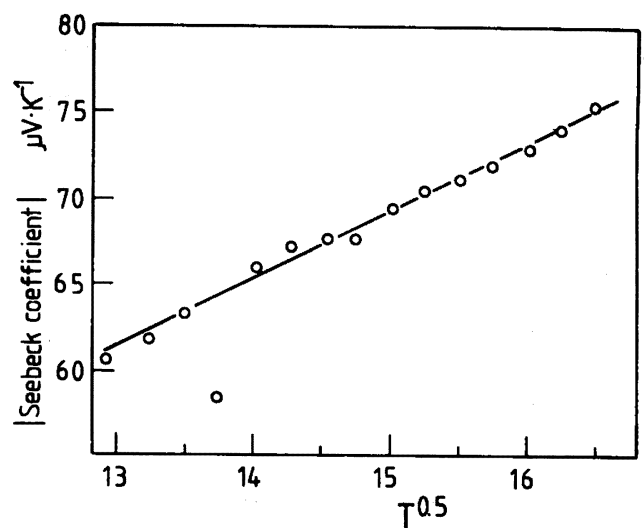

Fig. 9. Tempepature dependence of the Seebeckcoefficient of polyazulene.

のであった．これは，定電流電解では重合時間の経過と ともに酸化電位が変化し, 最適酸化電位加らはずれるた めであると考えられる.

また, 酸化電位を変えても, 得られた重合体に含まれ るアニオン量は約 $65 \mathrm{~mol} \%$ でほぼ一定であった。これ は, 電気伝導度を左右しているものが, この場合はア二 オン量ではなく，ポリマーそのものの性質であることを 示唆している.

Fig. 6 に酸化電位を変化させて得た重合体の活性化工 ネルギーを示した，電気伝導度のグラフに対応して 1.8 $\mathrm{V}$ で極小值を示し，これより低い電位では活性化エネル ギーは急激に増大し，また，これより高い電位では緩や かな増加を示した. Fig. 5 と Fig. 6 を比較して興味深い ことは, 同じ電気伝導度を与える酸化電位であっても, 活性化エネルギーは異なっていることである.この点に ついて, $1.8 \mathrm{~V}$ 以下の酸化電位で電気伝導度が小さいの は活性化エネルギーが大きいためであり, $1.8 \mathrm{~V}$ 以上の 電位で電気伝導度が小さいのは活性化エネルギー以外の 要因によるものと考えられる.すなわち，酸化電位が低 
い場合に活性化エネルギーが大きくなる原因は，十分に 高分子鎖が生長するだけの酸化電位が与えられず, 個々 の分子鎖が短いため, 高分子鎖間の電荷の移動に要する エネルギーが大きくなることに起因していると考えられ ろ. 酸化電位が高すぎる場合は, アズレン罟同士の架橋 が電子密度の最も高い1位や3位だけでない,これらの 位置に電子密度のが接近している5 位でも起こるため に、重合体が枝分かれ構造をとることにより電気伝導度 の低下をきたしているすのと思われる.

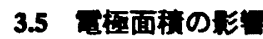

モノマーや支持電解質の浱度が同じであってあ，ま た, 酸化電位が同じであっても, 電極面積に違いがおれ ば, 反応に寄与する基質への影䇾が考えられる. そこで, モノマー浱度 $0.01 \mathrm{M}, \mathrm{TBAClO}_{4}$ 浱度 $0.1 \mathrm{M}$ のベンソニ トリル溶液 $(50 \mathrm{ml})$ を用い, 3 種の作用極面積で, $1.8 \mathrm{~V}$ の定電位酸化を行って得られた重合体の電気伝導度を比 故した. その結果を Table 2 に示す. 表に示すとおり,こ れまでの実験で用いてきた $15 \mathrm{~cm}^{2}$ の電極の場合に比べ $\tau, 2 \mathrm{~cm}^{2}$ の電極を用いた場合には, 1 桁程度電気伝導度 が上昇した。このことは，上り高い電気伝導度を示す重 合膜を得るためには，反応のスケールに応じた大きさの 電極を用いることが必要であることを示唆している.

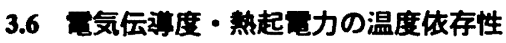

最も高い電気伝導度を示したサンプルについて, 室温 から $100 \mathrm{~K}$ までの温度範囲で電気伝導度の測定を行っ た. Fig. 7 に示すとおり, 温度の低下とともに電気伝導 度が低下する半導体的な挙動を示した. $\log \sigma$ と $T^{-1}$ の 間には良い直線関係がみられなかったが, $\log \sigma$ と $T^{-0.25}$ の間には良い直線関係が観察された (Fig. 8).これは,

無機アモルファス半導体で観察される3 次元バリアフル レンジホッピングに特徵的な現象》である。 この結果は ボリビロールの場合")之同様であり，へテロ原子を持た ないことや 7 員懪が縮㻴していることは, 電子伝達機構 に影整しないことを意味している.

また，熱起舟力”を $300 \mathrm{~K}$ から $150 \mathrm{~K}$ の温度範囲で測 定したところ, 測定した温度範囲では高温側が負電位に なるP型半導体の挙動を示した.これは, 重合体にドー フされているアニオンが, 高分子銷から電子を奪い正孔 キ+リアを発生させていると考えることができる. Fig. 9 に示すように, 熱起電力の絶対値は $T^{0.5}$ に比例した. このことも,ポリアスレンの電気伝尊がホッピング伝導 が支眍的である ${ }^{109}$, 11)ことを支持している. しかし, 熱起 電力の温度依存性から求められる活性化エネルギーは, およそ $10 \mathrm{meV}$ であり, 電気伝導度の温度依存性から求 めた値（約 $80 \mathrm{meV}$ ) の約 10\%であった. 現時点ではこ の不一致の原因を, 電気伝導度はマクロな構造に依存 し, 熱起電力がミクロな構造に依存しているためである のではないかと考えているが, その明確な回答を得るに
は至っていない。

\section{4 ま とめ}

より高い電気伝導度を示すアスレン重合体を得るため に, 電解重合反応におけるさまさまな要因について検討 を行った. その結果は以下のとおりである.

1. アススンの電解重合は, 溶媒にベンソニトリル, 支持電解質に過塩素酸テトラブチルアンモニウムを用い る組合せが, 高い電気伝導度を示す重合体を与える.

2. 高い電気伝導度を示す重合体を得るためには，モ ノマー濃度に比べて支持電解質の襄度を高くすべきで, およそ，モノマー濃度が $0.01 \mathrm{M} \sim 0.1 \mathrm{M}$, 支持電解質濃 度が $0.1 \mathrm{M}$ 以上が好ましい。

3. 仕込み支持電解質濃度を高くするにつれて, 重合 膜にドープされるアニオン量は多くなるが, 約 $67 \mathrm{~mol} \%$ （モノマーユニット三つに対してアニオンニつ）より高 くはならない. また, アニオンのドープ量の增加に対応 して電気伀導度も上昇するが，ドープ量が約 $67 \mathrm{~mol} \%$ で電気伝導度も頭打ちとなる。

4. 定電位電解の方が定電流電解より高い電気伝導度 を示す重合体を得ることができ，最適な重合電位は 1.8 $\mathrm{V}$ (vs. $\mathrm{Ag} / \mathrm{AgCl})$ であった.

5. 電解重合膜の電気伝導度は, 電極面積の影響も受 けることがわかった. すなわち, より高い電気伝導度を 有する重合体を得るためには, 反応スケールに適した大 きさの電極を用いる必要があることが確認できた。

6. 電気伝導度及び熱起電力の温度依存性から, 重合 膜の電気伝導機構は, ホッピング伝導であることが示唆 された.

\section{文献}

1) T. A. Skotheim, Ed., "Handbook of Conducting Polymers", Marcel Dekker Inc., New York, N. Y. (1986).

2) 例えば, A. Tumura, H. Koezuka, and T. Ando, Appl. Phys. Lett., 49, 1210 (1986).

3) 例えば M. Salmon, A. F. Diaz, A. J. Logan, M. Krounbi, and J. Bargon, Mol. Cryst. Liq. Cryst., 93, 2791297 (1983).

4) J. Bargon, S. Mohamand, and R. J. Waltman, Mol. Cryst. Liq. Cryst., 93, 279 (1983).

5) P. M. Chaikin and J. F. Kwak, Rev. Sci. Instrum., 46, 248 (1975).

6) R. M. Dessau and S. Shih, J. Chem. Phys., 53, 3169 (1970).

7) N. F. Mott, "Conduction in Non-Crystalline Materials", Oxford University Press, Oxford (1987).

8) 例えば, K. K. Kanazawa, A. F. Diaz, W. D. Gill, P M. Grant, G. B. Street, G. P. Gardini, and J. F. Kwak, Synth. Met., 1, 329 (1979/80).

9) ポリピロールの测定例，例えば，a) 文献 8; b) S. Miyauchi, S. Ohta, Y. Sorimachi, and I. Tubata, Polym. Prepr. Jpn., 36, 1997 (1987); c) Y. Shen, K. Carmeiro, C. Jacobsen, R. Qian, and J. Qiu, Synth. Met., 18, 77 (1987). 
10) N. F. Mott and E. A. Davis, "Electronic Processes in NonCrystalline Materials", Clarendon Press, Oxford (1979).
11) R. Colson and P. Nagel, J. Non-Crystalline Solids, 35, 129 (1980).

\section{The Optimum Conditions for Electrochemical Polymerization of Azulene}

Kentaro IwASAKI ${ }^{* 1,}{ }^{* 2}$, Yasuo TANEDA*1, Kazuo MATSUMoto, and Shojun Hino*1

*1 Faculty of Engineering, Chiba University (Yayoi-cho, Chiba, 260 Japan)

*2 Department of Structual Molecular Science. The Graduate University for Advanced Studies

(in IMS, Myodaiji-cho, Okazaki, 444 Japan)

Electrochemical polymerization of azulene was carried out systematically to find out the optimum polymerization conditions. Synthesizing solvents were dehydrated dexygenated benzonitrile, acetonitrile and dimethylformamide, and supporting electrolytes were recrystallized tetrabuthylammonium salts. The electrical conductivity, $\sigma$, of the pristine polymers is used to evaluate the quality of the polymers. Higher than $0.1 \mathrm{M}$ concentration of supporting electrolyte in the synthesizing solution gives polymers of $\mathrm{ca} .65 \mathrm{~mol} \%$ content of the anions, and high conductivity of around $0.5 \mathrm{~S} /$ $\mathrm{cm}$. A potential of $1.8 \mathrm{~V}$ applied to the reference electrode $(\mathrm{Ag} / \mathrm{AgCl})$ gives the largest conductivity and the smallest band gap energy. A linear relation between $\log \sigma$ and $T^{-1 / 4}$ is observed. This suggests that the conduction mechanism in polyazulene is variable range hopping. The temperature dependence of the thermo electric power also supports this conclusion.

KEY WORDS Polyazulene / Electrochemical Polymerization / Conducting Polymer / Thermo Electric Power / (Received May 17, 1990 : Accepted August 8, 1990)

[Kobunshi Ronbunshu, 47(11), 889-894 (1990)] 